\title{
The Effects of Top Management Commitment on Operational Performance Through the Use of Information Technology and Supply Chain Management Practices
}

\author{
Fernaldi Darmasaputra Leksono ${ }^{1}$, Hotlan Siagian $^{1 *}$, and Selvie Josowanto Oei ${ }^{2}$ \\ ${ }^{1}$ Faculty of Business and Economic, Petra Christian University, \\ Jl. Siwalankerto 121-131, Surabaya 60236, Indonesia \\ ${ }^{2}$ Dayeh University, No.168, University Rd., Dacun, Changhua 51591, Taiwan
}

\begin{abstract}
The company's performance must be continuously improved to be able to face the increasingly fierce global competition. The improvement of the company's performance can be made by implementing supply chain practices. The implementation of supply chain practice is a policy set by the company's top management by making the system integrated. Integration of all functions, internally and externally, is done by using integrated information technology. This study takes data from companies in East Java, engaged in machinery that has a workforce of more than 100 people - categorized as medium and large companies. Respondents were set on employees with a minimum of $2 \mathrm{yr}$ of working experience and a middle manager position. There were 55 respondents in this study, with data analysis using partial least square (PLS) to test the research hypothesis. The result of the data processing found that the commitment of top management affects the supply chain practices and the use of information technology. This is because the management has shown its commitment by providing the necessary human resources. The top management commitment directly influences the company's operational performance. The use of information technology directly affects supply chain practices and the company's operational performance. Supply chain practices affect the company's operational performance. This is because the company has carried out the process of information sharing with the company's suppliers to control and facilitate the procurement of quality raw materials.
\end{abstract}

Keywords: Firm performance, information quality, integrated system, supply chain application

\footnotetext{
* Corresponding author: hotlan.siagian@ petra.ac.id
} 


\section{Introduction}

In Indonesia, productivity is the main key in improving operational performance to become more efficient and have more competitive values. In addition to productivity, the low cost inputs used can also enable a country to compete. The low labor cost has become a factor that often used by a country to have operational performance. Operational performance is based on the thought that an organisation is a group of productive assets, including human, physical resources, and capital, which aims to achieve common goals. The concept states that these assets will only survive in the organisation as long as these assests are satisfied with the value they are performing that related to the organisation's internal work such as productivity, the quality of the product, and customer satisfaction. Consequently, the core of the performance is the creation of a value [1].

The practice of supply chain management has an impact on the company's operational performance [2]. This is achieved through the effective cost required in carrying out a series of supply chain management activities with contributions from the suppliers. The implementation of supply chain management practices can also have an impact on a company's operational performance, both manufacturing and services. Supply chain management practices can improve relationships between companies and suppliers and customers [3]. This can increase customer satisfaction so that it can improve the company's operational performance. The supply chain management practices have a direct impact on operational performance [4]. Supply chain management practices are one of the highest priorities for top management in companies looking for solutions to improve their operational performance [5]. Information technology (IT) now plays a role in innovation and development and helps companies to provide better services to the customers so as to improve their operational performance. The use of information technology is important to be developed and updated continuously. The research explains that information technology can provide operational performance for companies on an ongoing basis [6]. The use of information technology has a significant impact on product quality that is able to provide operational performance for the company [7]. The use of information technology to create good operational performance in relation to logistics [8]. Investment in information technology and its use for efficient supply chain management practices should be implemented in the company [9]. Supports the statement by stating that information sharing using information technology can improve the performance of supply chain management practices [10]. Using information effectively and efficiently in accordance with what has been supported by the use of information technology.

Supply chain management practices can only be successfully implemented and developed in companies with the support and commitment of the company's top management [11]. The commitment of top management has a significant relationship with the ongoing process of supply chain management activities [12]. The success of supply chain management practices, commitment from top management also affects the use of information technology in the company. Strategic information systems planning in organizations, top management must dedicate themselves with adequate resources, control, and support [13]. Companies can build internal integration by integrating departments within the company and are also capable of external integration [14]. Reveals that company performances can be improved by providing SCM practice and implementing information technology [15].

The long period of time will potentially result in late product completion being late. This condition requires the company to use information technology that is integrated between one function to another. Information technology is used in order to quickly control all the materials in the warehouse and know the procurement of materials made by the 
procurement department, and to be able to estimate the arrival time of materials and material processes in the company's production department. Information technology used in companies strongly supports supply chain practices in performing collaboration and communication and coordination with internal and external parties of the company. The use of existing information technology helps company leaders and all staff in making decisions in accordance with the work area under their scope. The study has three broad research objectives, namely testing the effect of top management commitment on the use of information technology, supply chain practice, and operational performance. Second, testing the effect of information technology implementation on supply chain practice and operational performance, and finally testing the effect of supply chain practice on operational performance.

\section{Background theory}

Supply chain management includes coordination and collaboration with related partners, which can be suppliers, intermediaries, third parties as service providers, and customers, or consumers. Basically, supply chain management integrates supply and demand arrangements within or between companies [16]. Supply chain management is a collection of approaches to integrating raw material suppliers, manufacturing companies, warehouses, and shops or sellers so that goods can be produced and distributed with the right amount, location, and time.

\subsection{Supply chain practice}

Supply chain management in companies acts as a tool for companies to improve their performance and maintain their level of competition against their competitors. Supply chain management practice is defined as a collection of activities carried out within an organisation in increasing the effectiveness in supply chain activities [17]. Supply chain management practice is a multidimensional concept in which dimensions of supply chain management practice are Strategic supplier partnership, Customer relationship, level of information sharing, quality of information sharing, and postponement. The company's management commitment influences the implementation of better supply chain management practices in Chinese companies, with 245 questionnaires out of 500 questionnaires distributed using Lisreal. Management commitment to the company has an increasing impact on the implementation of supply chain practices by integrating the company's internal and external data. External integration with companies related to the company's suppliers and customers [18]. USA manufacturing companies states that SCM practice is able to provide an improvement in the company's operational performance [19]. This explains that SCM company practices along with information sharing, long term relationships, advanced planning systems and supply network structure are capable to provide accurate product delivery, the company's product quality which is better than its competitors, the company's costs of production which are lower than its competitors and the company's profits which are better than its competitors.

\subsection{Information technology implementation}

Information can be defined as a set of structured data that can be communicated through various means, such as in verbal, in writing, or in visual using various communication media. Information can also be interpreted as data that is processed in such a way that it can be useful for its users and assist them in the decision making process, both short-term and 
long-term decisions. The information has three main aspects, which are accuracy, timely, and relevant. Information, which will be used in the decision-making process, must be error-free because interference is likely to occur in the information reaching the recipient that can change or damage the information. Successful implementation of information technology as a support for supply chain management depends on the support of top management and the overall organisational structure. The indicators used for information technology systems are data integration between departments, information technology software that is used as needed, information technology hardware that is used as needed, and the quality of information the company can rely on. Top management commitment has an influence on internal information systems related to information timelines, information gathering, and information integration on 200 chief financial officers or chief accounting officers of the best companies in Australia using linear regression [20]. Information and communication technology at companies with levels of information qualification, information timeline, information availability, internal and external communication, and lastly information flow is carried out with the commitment of the company management of the Iranian financial institution registered with the Central Bank in Iran with as many as 84 questionnaires using the PLS Analysis [21].

The information technology used by electronic companies in Malaysia by sharing information with external parties will provide an increase in supply chain management practices in building coordination with suppliers, which called supplier relationship management and with external parties called customer relationship management. The information technology used by the company and shared with the company's internal parties and related departments; and external companies such as suppliers and customers of the company can improve the company performance, especially in improving the coordination and collaboration with suppliers and customers and increasing sales at 100 electronics companies in Malaysia - 600 questionnaires were distributed [22].

\subsection{Top management commitment}

Top management commitment in supply chain management has become important as it is one of the important conditions for the successful implementation of supply chain management. Top management facilitates the empowerment of the employees and the increased job satisfaction through leadership in order to achieve the goal, which is customer satisfaction. The top management always strives in the implementation of the Supply Chain Management system in the company by taking responsibility and authority in implementing an effective SCM system. Top management of the company ensures that policy making and targeting are adjusted to the internal and external conditions of the company.

The top management of the company ensures that there is integration between business processes within the company with external and internal parties of the company. The integration is built in the intention to provide an efficient and effective flow of supply chain management processes. The company's management also ensures that the resources needed in implementing supply chain management are available in accordance with the requirements. The management builds good communication and coordinates and collaborates with the parties involved in developing the supply chain management system within the company. The company's internal conditions must be controllable by the management in order to involve and empower all components in the company to contribute to improving company performance by carrying out supply chain management practically.

Company organisations under the leadership of the top management should provide people competent in effectively and efficiently carrying out company operations, and controlling the company's operations on an ongoing basis [23]. Good commitment of the management will be able to implement supply chain management to carry out supply chain 
practices, develop supply chain management systems and increase the effectiveness of supply chain management flows. The acceleration of the implementation and development of supply chain management needs an integrated information technology within the company. Indicators used to measure the variable of the commitment of top management are: conducting good communication, setting company goals, providing the necessary human resources, providing the necessary financial resources, and carrying out adequate operational control [24]. The same research also states that the support of the company's top management is closely correlated with project performance, and has an impact on the performance of information technology projects [23]. Research conducted by Alfalla-Luque et al., [25] on 262 large manufacturing companies, states that commitment from employees and company leaders will improve company performance [4].

\subsection{Operational performance}

Performance is an expression of ability based on knowledge, attitudes, and motivation in producing a job. This explains that performance is a record of the working result in a certain period of time, which is obtained from measuring the quantity and quality of an organisation [26]. Performance is the result of the quality and quantity of work achieved by employees of an organisation in carrying out their duties according to their responsibilities given by the organization [27]. The internal work of the organisation, such as productivity, product quality, and customer satisfaction [1]. Operational performance is also connected to the development and innovation within the organisation that can support the organisation's financial performance in the future. The operational performance allows manufacturing / production lines to be competitive in producing products [28]. Operational performance are measured by product quality, on time product delivery, product cost, flexibility in the number of products, and flexibility in product variations [29]. The operational performance is performance in product quality, product delivery accuracy, product delivery reliability, and operational cost [14].

\subsection{Conceptual framework and research hypothesis}

The commitment of the company's top management on an ongoing basis is capable of providing financial support, resource support for companies that use information technology. The information technology used by the company allows them to build internal integration so that there is data integration between functions within the company, and external integration of the company so that suppliers and customers can get accurate information about the company's needs and planning. Information technology built by the company is expected to be competent in providing information to outside parties so that the supply chain management practice can be carried out properly. This condition is obtained by quickly knowing the information inside the company so that the company is able to develop supplier relationship management and customer relationship management. The overall condition of this system is able to provide company performance. Based on the explanation above, it can be determined by the following research hypothesis:

H1: The commitment of the top management influences the use of information technology in manufacturing companies.

$\mathrm{H} 2$ : The commitment of the top management influences the implementation of supply chain practices in companies.

H3: The commitment of the top management influences the performance of manufacturing companies.

H4: The use of information technology influences the supply chain practice in East Java manufacturing companies. 
H5: The use of information technology influences the company performance of East Java manufacturing companies.

H6: Supply chain practice influences the company performance of East Java manufacturing companies.

\section{Research methodology}

Explanatory is a research that aims to analyze the relationships between one variable with another variable in which explanatory is a causal relationship. The unit of analysis for companies with the population is taken from manufacturing companies in the East Java region. In East Java, there are 104 manufacturing companies with employees of more than 100 manufacturing companies based on the data information on the East Java Central Statistics Agency website. The sampling technique in this study uses a non-probability sampling method called judgement sampling. Judgment sampling is a method of sampling by taking samples from the population based on criteria in the form with a particular consideration. Research respondents are the company's employees with a minimum of two years of working experience in that company, so that it allows them to have an understanding and experience of the company where they work.

The data collection used a Likert scale approach, where the answers are given between 1 (strongly disagree) to 5 (strongly agree) through the distribution of the questionnaires. The data analysis methods used by the researcher to test the hypothesis provided are the Structural Equation Modeling technique, which is abbreviated to SEM. In addition to that are the Partial Least Square (PLS) program and SmartPLS software.

\section{Research analysis and discussion}

The description of the respondents based on the departments of 55 companies that were sampled in this study is listed in the Marketing department as many as 17 respondents, with a percentage of $31 \%$. This happens because the Marketing department is the main line in the company that starts a sequence of supply chain management. The marketing department is a department that receives orders from customers and then forwards the order to the subsequent departments involved in the process of making the product or service ordered. The second place is the Purchasing department: 15 respondents with a percentage of $27 \%$. This happens because the Purchasing department is a department that is vital in a series of supply chain management activities since it purchases the items needed to produce orders desired by the customer. Next is the Production department: 11 respondents with a percentage of $20 \%$. The Production department is the third highest department, where respondents in this study work. This happens because the Production department is the midpoint of a series of supply chain management activities. The Production Department is a place where all raw materials from suppliers are processed to be products that are ready to be shipped to customers. The fourth place is the Warehouse department with eight respondents with a percentage of $15 \%$. The Warehouse Department is directly responsible for the stock of goods in supply chain management activities, both raw materials, semifinished goods, or finished goods, so that their quantity and availability are controlled. In the last place are the Production Planning and Inventory Control (PPIC) department, with a total of four respondents with a percentage of $7 \%$. The PPIC department is a department responsible for production planning and stock availability to ensure the production process can run smoothly. This description shows that the respondents in this study were 
respondents from key departments in a series of supply chain management activities within a company.

Respondents who filled out the questionnaires in this study were dominated by those who have worked for the company for more than $10 \mathrm{yr}$, as many as 22 people with a percentage of $40 \%$. The second place of respondents who filled out the questionnaires in this study is those who have worked for the company between $5 \mathrm{yr} \leq 10 \mathrm{yr}$, as many as 16 people with a percentage of $29 \%$. The third place of respondents who filled out the questionnaires in this study is those who have worked for the company between $3 \mathrm{yr} \leq 5 \mathrm{yr}$, as many as 12 people with a percentage of $22 \%$. The fourth place of respondents who filled out the questionnaires in this study is those who have worked for the company between $2 \mathrm{yr}$ $\leq 3 \mathrm{yr}$, as many as five people with a percentage of $9 \%$. This description shows that respondents in this study have worked long enough to have an understanding of work processes in the company where they work.

Testing of the compatibility of the model through validity testing of the PLS was carried out using the goodness of fit outer model and inner model evaluation generated by the SmartPLS program. The measurement model or outer model is evaluated by convergent validity and composite reliability for the indicator block. Outer models are often referred to as outer relations or measurement models indicated by the value of the outer loading. Information technology application is measured using four indicators. The first indicator is data integration between departments that have gone well (IT1) with a factor weight of 0.756. The second indicator is information technology software that is used as needed (IT2) with a factor weight of 0.847 . The third indicator is information technology hardware that is used as needed (IT3) with a factor weight of 0.842 . The fourth indicator is the quality of information the company can rely on (IT4) with a factor weight of 0.802 . The results of the loading factor from the four indicators on the variable of information technology application show the results of the correlation of indicators with their variables that meet the requirements of convergent validity. This is because all the loading factors of the indicators exceed 0.5 .

Operational performance variables are measured using four indicators. The first indicator is the company's product quality is on demand (OP1) with a factor weight of 0.816. The second indicator is the accuracy of the order delivered for corporate customers (OP2) with a factor weight of 0.757 . The third indicator is the flexibility of the schedule of the product delivery (OP3) with a factor weight of 0.807 . The fourth indicator is the variation of the company's products according to customer needs (OP4) with a factor weight of 0.753 . The results of loading factors from the four indicators on operational performance variables show that the results of the correlation of the indicator with their variables meet the requirements of convergent validity because all loading factors of the indicators exceed 0.5 .

The variables of the supply chain practices are measured using six indicators. The first indicator is the company builds a partnership with suppliers (SCP1) with a factor weight of 0.714. The second indicator is an information sharing with company suppliers (SCP2) with a factor weight of 0.833 . The third indicator is the accuracy of the information that is easily obtained (SCP3) with a factor weight of 0.711 . The fourth indicator is the completeness of the information that is sufficient (SCP4) with a factor weight of 0.676 . The fifth indicator is the on time delivery in sending raw materials to the company (SCP5) with a factor weight of 0.803 . The sixth indicator is the fulfillment of goods from suppliers according to company demand (SCP6) with a factor weight of 0.825 . The results of loading factors from the six indicators on the supply chain practices variable show that the results of the correlation of indicators with the variables meet the requirements of convergent validity because all the loading factors of the indicators exceed 0.5 . 
The top management commitment variable is measured using five indicators. The first indicator is that the management communicates well with departments related to the supply chain (MC1) with a factor weight of 0.709 . The second indicator is that the management clearly sets company goals (MC2) with a factor weight of 0.754 . The third indicator is to provide the necessary human resources (MC3) with a factor weight of 0.760 . The fourth indicator is to provide the required funding resources (MC4) with a factor weight of 0.734 . The fifth indicator is to do adequate operational control (MC5) with a factor weight of 0.646. The results of loading factors from the five indicators on the variable top management commitment shows that the results of the correlation of indicators with the variables meet the requirements of convergent validity because all the loading factors of the indicators exceed 0.5 .

The reliability test was carried out using two methods, namely Cronbach's Alpha. The information technology application has a cronbach's alpha value of 0.828 . The operational performance variable has a cronbach's alpha value of 0.791. Supply chain practices have a Cronbach alpha value of 0.855 . The top management commitment variable has a Cronbach alpha value of 0.768 . All cronbach's alpha values exceeding 0.6 which can be said that this variable is reliable. The requirements of validity and reliability test have been fulfilled. Therefore the research hypothesis test processing can be done (Table 1).

Table 1. Path Coefficient

\begin{tabular}{|l|r|r|r|r|c|}
\hline \multicolumn{1}{|c|}{ Effect Variable } & \multicolumn{1}{c|}{$\begin{array}{c}\text { Original } \\
\text { Sample } \\
(\mathbf{O})\end{array}$} & $\begin{array}{c}\text { Sample } \\
\text { Mean } \\
\text { (M) }\end{array}$ & $\begin{array}{c}\text { Standard } \\
\text { Deviation } \\
\text { (STDEV) }\end{array}$ & $\begin{array}{c}\text { T Statistics } \\
(\mathbf{O} / \text { STDEV| }\end{array}$ & $\begin{array}{c}\text { P } \\
\text { Value }\end{array}$ \\
\hline $\begin{array}{l}\text { Top Management Commitment -> } \\
\text { Operational Performance }\end{array}$ & 0.478 & 0.475 & 0.105 & 4.550 & 0.000 \\
\hline $\begin{array}{l}\text { Top Management Commitment -> } \\
\text { Information Technology } \\
\text { Application }\end{array}$ & 0.758 & 0.764 & 0.048 & 15.645 & 0.000 \\
\hline $\begin{array}{l}\text { Top Management Commitment -> } \\
\text { Supply Chain Practices }\end{array}$ & 0.394 & 0.401 & 0.115 & 3.412 & 0.001 \\
\hline $\begin{array}{l}\text { Information Technology } \\
\text { Application -> Operational } \\
\text { Performance }\end{array}$ & 0.228 & 0.227 & 0.101 & 2.251 & 0.024 \\
\hline $\begin{array}{l}\text { Information Technology } \\
\text { Application -> Supply Chain } \\
\text { Practices }\end{array}$ & 0.477 & 0.472 & 0.113 & 4.229 & 0.000 \\
\hline $\begin{array}{l}\text { Supply Chain Practices -> } \\
\text { Operational Performance }\end{array}$ & 0.271 & 0.274 & 0.093 & 2.906 & 0.004 \\
\hline
\end{tabular}

Table 1. shows that the variable of top management commitment influences the supply chain practices in which the path coefficient for this relationship is 0.394 with a T-Statistics of 3.412. The management is committed to providing the necessary human resources to support the implementation of supply chain practices, especially in sharing information with the company's suppliers as part of the strategy in facilitating the procurement of raw materials. It is done so that the production process does not run out of raw materials due to the absence of a supply of raw materials from the suppliers. It states that top management commitment affects the implementation of corporate information technology [20,21].

Table 1. shows that the commitment of the top management has an influence on information technology application, in which the path coefficient for this relationship is 0.758 with T-Statistics 15.645 . The management is committed to providing the necessary human resources to support the use of information technology software that has been provided according to company needs. It is done so in order to maximize the use and 
function of information technology software in providing data and information needed for the top management of the company. This research is in line with research conducted by [30]. It states that the commitment of top management affects the implementation of company information technology. The management's commitment is able to make an increase in supply chain practice and supply chain integration in terms of using the information technology with internal integration and external integration [22].

Table 1. shows that the commitment of the top management influences the operational performance, in which the path coefficient for this relationship is 0.478 with T-Statistics 4.55. Management is committed to providing the necessary human resources to guarantee the quality of the products produced by the company. It is done by carrying out quality control so that the quality of the product is in accordance with the demands or expectations of the customers. This study is in line with the research conducted by Kanwal et al. [23] and Alfalla-Luque et al. [25], which states that top management commitment affects company performance. Commitments that are built together by the company leaders and employees are able to provide an improvement in the company performances. This research is also in line with the research by Tarigan et al. [31], which states that organisational commitment consisting of top management commitment and employee commitment is capable of providing an improvement on the company performances.

Table 1. shows that the information technology application has an influence on supply chain practices, in which the path coefficient for this relationship is 0.477 with T-Statistics 4.229. The necessary use of information technology software will support the process of sharing information with suppliers to control and facilitate the procurement process that can be done through information technology. Therefore, it can be done more quickly and accurately. This study is in line with the research conducted by Gandhi et al. [14] and Sundram et al. [22], which states that the application of information technology affects the company's performance. This study also supports the results of the study by Tarigan et al., [31] in which states that the use of information technology in the form of ERP applications affects the supply chain practice of manufacturing companies.

Table 1. shows that the information technology application has an influence on operational performance, in which the path coefficient for this relationship is 0.228 with a T-statistic 2.251. The information technology software, provided according to the needs, is used by the company to support the process of quality control in order to make it easier to do so that the quality of the products produced by the company is in accordance with the demands or expectations of the customers and will increase customer satisfaction. This study is in line with the research conducted Cook et al. [19], which states that the application of information technology affects the company's performance. This study supports the results of research conducted by Anuar and Yusuf [32] on SME companies in Malaysia, stating that the use of information technology applications can improve company performance. This study is in line with the results of research by Saeidi et al. [21] which talks about information technology in the Iranian financial institution.

Table 1. shows that supply chain practices have an influence on operational performance, in which the path coefficient for this relationship is 0.271 with T-Statistics 2.906. The company shares information with the suppliers to control and facilitate the procurement of quality raw materials so that the quality of the products produced by the company can be in accordance with the demands or expectations of the customers and increase the level of customer satisfaction. The SCM practices affect company performance $[19,32]$. This study also supports the results of Gorane and Kant's [33] research on manufacturing companies in India and also Wang and Dai's research [34], which states that supply chain practice in companies can improve company performance. 


\section{Conclusion}

Several conclusions can be drawn from the results of data processing and analysis carried out in this study. The commitment of top management affects supply chain practices. This is because the management has demonstrated its commitment by providing the human resources needed to support the implementation of supply chain practices, especially in sharing information with suppliers as part of the commitment of the top management, which affects the use of information technology. This is because management has demonstrated its commitment by providing the human resources needed to support the use of information technology software which is provided according to company needs to maximize the use and function of information technology software in providing data and information needed for the top management in the company as a strategy to facilitate the process of procuring raw materials so that the production process does not run out of raw materials caused by the absence of supply of raw materials from suppliers. This is because the management has demonstrated its commitment to providing human resources needed to guarantee the quality of the products produced by the company - by conducting quality control so that the quality of the products meets the demands or expectations of the customers.

The use of information technology affects supply chain practices. This is due to the use of information technology, the information technology software, as needed so that it supports the sharing information process with the suppliers to control and ease the procurement process so that it can be done more quickly and accurately. The use of information technology affects the company's operational performance. This is due to the use of information technology, the information technology software, as needed to support the quality control process so that it can be done easier and the quality of the products produced by the company will meet the demands or expectations of the customers, hence improve the customer satisfaction.

Supply chain practices affect the company's operational performance. This is because the company has carried out the process of sharing information with the company's suppliers to control and facilitate the procurement of quality raw materials so that the quality of the products produced by the company can meet the demands or expectations of the customers and increase the level of customer satisfaction.

\section{References}

1. P.J. Zelbst, K.W. Green, V.E. Sower, R.D. Abshire, Management Research Review, 37,11:970-989(2014). https://www.emeraldinsight.com/doi/abs/10.1108/MRR-102014-273

2. S.B. Ibrahim, A.A. Hamid, International Journal of Science and Research, 3,8:187195(2014).

https://pdfs.semanticscholar.org/4b49/461dc477f5b3a2eef42df68d617199863d01.pdf

3. J.D. Wisner, K.C. Tan, G.K. Leong, Principles of Supply Chain Management, Ohio: South-Western (2012). http://www.sap-project.ca/SCMP/CHAPTER1READING.pdf

4. D. Bratić, IBIMA Business Review, 2011:1-13(2011). http://ibimapublishing.com/articles/IBIMABR/2011/957583/957583.pdf

5. F. Fulconis, G. Paché, Competitiveness Review: An International Business Journal, 15,2:92-100(2005). https://www.emeraldinsight.com/doi/abs/10.1108/cr.2005.15.2.92

6. J. Chi, L. Sun, Modern Economy, 6:404-410(2015). https://pdfs.semanticscholar.org/61ef/5aae93b9c05d6237d8307e0dac487b0a6480.pdf

7. S. Lim, S. Trimi, Journal of Business and Management, 3,1:1-12(2014). https://pdfs.semanticscholar.org/1839/bbc51ab2765b10180e32db5f6642e8059b72.pdf 
8. B.T. Hazen, T.A. Byrd, International Journal of Physical Distribution \& Logistics

Management, 42,1:8-35(2012).

https://www.emeraldinsight.com/doi/abs/10.1108/09600031211202454

9. S.W. Kim, Asian Journal on Quality, 13,3:250-267(2012).

https://www.ingentaconnect.com/content/mcb/ajq/2012/00000013/00000003/art00004

;jsessionid=doblq96oo2i1n.x-ic-live-02

10. P. Jonsson, P. Myrelid, International Journal of Operations \& Production

Management, 36,12:1769-1799(2016).

https://www.researchgate.net/publication/309379355_Supply_chain_information_utili sation_conceptualisation_and_antecedents

11. F. Talib, Z. Rahman, M.N. Qureshi, International Journal of Productivity and Performance Management, 60,3:268-288(2010).

https://www.emeraldinsight.com/doi/abs/10.1108/17410401111111998

12. K. Hayat, A. Abbas, M. Siddique, K.U. Cheema, Munich Personal RePEc Archive, 3,3:1-13(2012). https://mpra.ub.uni-muenchen.de/id/eprint/53193

13. M.L. Perera, C.C. Jayasundara, Academy of Contemporary Research Journal, 2,4:161-170(2013).

https://www.academia.edu/28495559/Impact_Of_IT_IS_Management_Commitment on_Strategic_Information_Systems_Planning_A_Study_of_Selected_Commercial_Ba nks in Colombo District Sri_Lanka

14. A.V. Gandhi, A. Shaikh, P.A. Sheorey, International Journal of Retail \& Distribution Management, 45,4:366-384(2017).

https://www.emeraldinsight.com/doi/abs/10.1108/IJRDM-06-2015-0076

15. K.W. Green, K.M. Casey, R. McGaughey, Supply Chain Management: An International Journal, 11,5:407-414(2013).

https://www.emeraldinsight.com/doi/abs/10.1108/13598540610682426

16. D.M. Gligor, Supply Chain Management, 19,5/6:577-591(2014).

https://doi.org/10.1108/SCM-10-2013-0363

17. S. Li, B. Ragu-Nathan, T. Ragu-Nathan, S.S. Rao, The International Journal of Management Science, 34,2:107-124(2006).

https://www.researchgate.net/publication/222028949 The Impact_of_Supply_Chain Management_Practices_on_Competitive_Advantage_and_Organizational_Performanc $\underline{\mathrm{e}}$

18. Y.H. Jin, A.M. Fawcett, S.E. Fawcett, International Journal of Physical Distribution \& Logistics Management, 43,3:205-230(2013).

https://www.emeraldinsight.com/doi/abs/10.1108/IJPDLM-10-2011-0169

19. L.S. Cook, D.R. Heiser, K. Sengupta, International Journal of Physical Distribution \& Logistics Management, 41,2:104-134(2011).

https://www.emeraldinsight.com/doi/abs/10.1108/09600031111118521

20. S.Y. Spencer, C. Adams, P.W. Yapa, Sustainability Accounting, Management and Policy Journal, 4,1:75-102(2013).

https://www.researchgate.net/publication/275317477_The_mediating_effects_of_the adoption_of_an_environmental_information_system_on_top_management's_commit ment and environmental_performance

21. P. Saeidi, S.P. Saeidi, S. Sofian, S.P. Saeidi, M. Nilashi, A. Mardani, Computer Standards Interfaces, 63:67-82(2019).

https://fardapaper.ir/mohavaha/uploads/2019/01/Fardapaper-The-impact-ofenterprise-risk-management-on-competitive-advantage-by-moderating-role-ofinformation-technology.pdf

22. V.P. Sundram, A.R. Ibrahim, V.G. Govindaraju, Benchmarking: An International Journal, 18,6:834-855(2011).

https://pdfs.semanticscholar.org/961b/88a2869f178dfac7d8a2a2575e4939d1bbef.pdf 
23. N. Kanwal, M.S. Zafar, S. Bashir, International Journal of Project Management 35:1459-1465(2017).

https://www.sciencedirect.com/science/article/pii/S0263786317306476

24. R.Ø. Skotnes, Information \& Computer Security, 23,3:302-316(2015).

https://www.semanticscholar.org/paper/Management-commitment-and-awareness-

creation-ICT-in-Skotnes/5d32ee418582d7ac01b65afc18a9eca805cd81a0

25. R. Alfalla-Luque, J.A. Marin-Garcia, C. Medina-Lopez, International Journal of

Production Economics, 162,1:242-257(2015).

https://www.sciencedirect.com/science/article/pii/S0925527314002217

26. Z.J.H. Tarigan, International Journal of Business and Society, 19,2:335-346(2018). http://www.ijbs.unimas.my/images/repository/pdf/Vol19-no2-paper6.pdf

27. A.P. Mangkunegara, Manajemen sumber daya manusia perusahaan. Bandung: PT Remaja Rosdakarya (2013). http://pustaka.pu.go.id/biblio/manajemen-sumber-dayamanusia-perusahaan/59BBE

28. S. Modgil, S. Sharma, Journal of Quality in Maintenance Engineering, 22,4:353377(2016).

https://www.researchgate.net/publication/309249980_Total_productive maintenance total_quality_management_and_operational_performance_An_empirical_study_of_In dian_pharmaceutical_industry

29. H. Jonsson, M. Rudberg, Construction Innovation, 17,3:381-403(2017). https://www.emeraldinsight.com/doi/abs/10.1108/CI-06-2016-0034

30. Y. Xiao, X. Zheng, W. Pan, X. Xie, Chinese Management Studies, 4,3:231243(2010). https://www.emeraldinsight.com/doi/full/10.1108/17506141011074129

31. Z.J.H. Tarigan, Lianto, S.R. Basana, The impact of organizational commitment on upgrading ERP for maintaining the quality of information and the ERP performance, IOP Conference Series: Materials Science and Engineering, 473:012051(2019). https://iopscience.iop.org/article/10.1088/1757-899X/473/1/012051/meta

32. A. Anuar, R.M. Yusuff, Benchmarking: An International Journal, 18,3:

324-341(2011).

https://www.emerald.com/insight/content/doi/10.1108/14635771111137750/full/html

33. S.J. Gorane, R. Kant, Benchmarking: An International Journal, 23,5:10761110(2016). https://www.emeraldinsight.com/doi/abs/10.1108/BIJ-06-2014-0059

34. J. Wang, J. Dai, Industrial Management \& Data Systems, 118,1:2-21(2018). https://www.mdpi.com/2071-1050/11/21/5949/pdf 